\title{
Os desafios da sustentabilidade nas comunidades rurais: uma análise nos sítios Cruzeiro e Jatobá, Crato/CE
}

As questões ambientais estão no escopo de todos os debates mundiais, a sustentabilidade se encontra presente em todos os diálogos que envolvem crescimento e desenvolvimento, mas o que se percebe, é uma grande quantidade de discursos e poucas ações efetivas. Identifica-se algumas ações pontuais em pequena escala geralmente provenientes de comunidades e associações que fogem ao modelo econômico capitalista, dando oportunidade a um novo tipo de economia com modus operandi na autogestão e processos colaborativos. Esse estudo tem por objetivo identificar os desafios da sustentabilidade nas comunidades rurais que sobrevivem da coleta de pequi nos Sítios: Cruzeiro e Jatobá na zona rural, da cidade do Crato/CE, utilizar-se-á um estudo descritivo, exploratório e observação participante através de rodas de conversa com a comunidade e entrevista semiestruturada com os representantes das famílias participantes do projeto, para mapear a comunidade e registrar o processo de construção do saber da comunidade, utilizando se uma abordagem qualitativa para a análise de conteúdo. Entendese que os desafios são elencados em todos os aspectos: a distância da zona urbana, o acesso, a escassez de água encanada e a ausência de energia trifásica além do desinteresse das políticas públicas em territorializar essa comunidade. A possibilidade da existência novas formas de organização da comunidade em torno do beneficiamento de pequi nos sítios Cruzeiro e Jatobá têm mudado a perspectiva e os sonhos dessa comunidade em não ter que sair do seu lugar, mas poder ter oportunidades de empoderamento, permitindo sua permanência e ampliando-as, a partir do beneficiamento do pequi.

Palavras-chave: Sustentabilidade; Beneficiamento de pequi; Comunidade rural.

\section{Sustainability criteria in rural communities: an analysis on the Cruzeiro and Jatobá sites, Crato/CE}

\begin{abstract}
Environmental issues are in the scope of all world debates, sustainability is present in all dialogues involving growth and development, but what is perceived is a large number of speeches and few effective actions. It identifies some small-scale, one-off actions usually coming from communities and associations that escape the capitalist economic model, giving opportunity to a new kind of economy with modus operandi in self-management and collaborative processes. This study aims to identify the sustainability challenges in the rural communities that survive from the pequi collection at the Cruzeiro and Jatobá sites in the rural area of the city of Crato/CE, using a descriptive, exploratory and participatory observation study through community conversation and semi-structured interviews with the representatives of the families participating in the project, to map the community and record the process of building community knowledge, using a qualitative approach to content analysis. It is understood that the challenges are listed in all aspects: the distance of the urban zone, the access, the shortage of piped water and the absence of three-phase energy beyond the disinterest of the public policies in territorializing this community. The possibility of the existence of new forms of community organization around the beneficiation of pequi in the Cruzeiro and Jatobá sites has changed the perspective and the dreams of this community in not having to leave its place, but to have opportunities of empowerment, allowing its permanence and enlarging them, from the beneficiation of pequi.
\end{abstract}

Keywords: Sustainability; Beneficiation of pequi; Rural community.

Topic: Uso Sustentável da Biodiversidade

Reviewed anonymously in the process of blind peer.
Received: 10/02/2018

Approved: 24/03/2018
Ana Isabel Calixto Donelardy

Universidade Federal do Cariri, Brasil

http://lattes.cnpq.br/3695894538207689

anaisabel@leaosampaio.edu.br

Claudia Maria Araújo Marco

Universidade Federal do Cariri, Brasil

claudia.marco@ufca.edu.br
Referencing this:

DONELARDY, A. I. C.; MARCO, C. M. A.. Os desafios da sustentabilidade nas comunidades rurais: uma análise nos sítios Cruzeiro e Jatobá, Crato/CE. Revista Ibero Americana de Ciências Ambientais, v.9, n.3, p.57-82, 2018. DOI: http://doi.org/10.6008/CBPC21796858.2018 .003 .0006 


\section{INTRODUÇÃO}

A contemporaneidade nos permite tecer estudos relacionados a perspectivas da sustentabilidade de forma mais contundente e consistente, pois na época da revolução industrial as ações de todas as esferas de comando e controle dos países se concentravam em instalar indústrias sem preocupações ambientais, porém nos anos 70 tornaram-se mundiais os questionamentos acerca da utilização inadequada dos recursos naturais, comenta Dias (2011).

A legislação ambiental foi instituída e alguns órgãos fiscalizadores começaram a atuar de forma eficaz, além disso, a regulamentação passou a ser exigida pelo mercado e pelos governos Valle (2004). É sabido que mesmo diante de tanta escassez de recursos naturais na atualidade, as atitudes individuais do ser humano ainda estão longe de vir a solucionar os danos causados durante os desacertos da busca pelo lucro incessante. A sustentabilidade surge como uma nova ordem de sobrevivência e equilíbrio e não mais aparece como um modelo utópico citado por Chacon (2007), mas, como uma realidade de pequena escala, as comunidades estão vivenciando modelos sustentáveis que precisam ser estudados e divulgados.

A construção dessa pesquisa surgiu a princípio depois das primeiras visitas à comunidade em setembro de 2014, a pesquisadora ao entrar em contato com a comunidade percebeu a carência em todos os aspectos naqueles moradores, essa visita inicial deu-se para a execução de um projeto de extensão cujo objetivo era elaborar projetos para melhorar a qualidade de vida daqueles os quais os alunos elegiam; e logo nas primeiras visitas identificou-se que os moradores dessa comunidade tinham o acesso muito restrito a água, sendo este bem primordial a existência humana, através de políticas públicas tiveram o acesso as cisternas de placas e captam a água das chuvas que abastecem essas cisternas para o uso doméstico, porém a quadra invernosa tem ficado cada vez menor e menos milímetros têm sido armazenados, nos meses de agosto até as próximas chuvas os moradores dessa comunidade são abastecidas por caminhões pipa que comercializam água uma vez por semana para os moradores que conseguem adquirir.

Conversando com os moradores logo detectou-se que a principal renda da comunidade é a aposentadoria e benefícios sociais, sendo o principal deles o bolsa família e o 'protagonista' identificado por eles como a principal fonte de renda é a coleta de pequi. Os sítios Cruzeiro e Jatobá localizam-se na zona rural da cidade de Crato/CE, nas imediações da chapada do Araripe, os moradores dessa comunidade, vivem da agricultura familiar e da coleta de pequi nos tempos de safra, porém a mesma tem um período de três a quatro meses, e observou-se que havia desperdício do poder de comercialização, pois o fruto é altamente perecível e precisava ser comercializado por valores irrisórios, isso traz prejuízos a comunidade, segundo alguns membros já foram queimados os frutos ou até enterrados pelo excesso de colheita, portanto a implantação de um galpão de beneficiamento de pequi nessa comunidade traria supostamente uma melhoria econômica e uma mudança na concepção de trabalho, relações e perspectivas.

Os estudos sobre problemas e soluções ambientais estão cada vez mais frequentes em todo o mundo, e o motivo se dá pela necessidade e dependência da sociedade pelos recursos naturais e de uma qualidade de vida melhor. O desenvolvimento sustentável, afirma Dias (2011) que surgiu nos anos 70 já 
preconizava isso quando na Comissão das Nações Unidas para o Meio Ambiente (CNUMAD) Brundtland afirmou que a população precisaria utilizar os recursos naturais de tal forma que estes não faltem para as gerações futuras.

Posteriormente as primeiras visitas surgiu o edital do banco Santander Universidades que traria uma premiação a uma comunidade, diante desse problema escreveu-se o projeto esse concorreu com mais oitocentos inscritos no Brasil sendo o projeto pequi vivo, dessa comunidade em estudo um dos premiados. A implementação de um galpão de beneficiamento de pequi nos Sítios Cruzeiro e Jatobá, surge como um modelo de negócio para evitar o desperdício do fruto, que em tempos de safra era desvalorizado e muitas vezes segundo a comunidade precisou-se enterrar ou queimar os frutos porque houve excedente de produção, sendo esse um caminho para a sustentabilidade.

Com a premiação em mãos da comunidade e alunos do projeto de extensão surge o questionamento: Quais os desafios da sustentabilidade essa comunidade enfrenta para sobreviver na zona rural?. Para tanto essa pesquisa objetiva-se por analisar os desafios da sustentabilidade nas comunidades rurais que sobrevivem da coleta de pequi na comunidade dos Sítios Cruzeiro e Jatobá na cidade de Crato/CE.

Para alcançar esse objetivo realizou-se um mapeamento do perfil sócio econômico de alguns representantes de núcleos familiares dessa comunidade, Identificou-se as principais atividades diárias realizadas por eles e os principais desafios para relaciona-los as dimensões da sustentabilidade proposta por Sachs (2000) e por entender que o projeto pequi vivo já faz parte do processo da sustentabilidade dessa comunidade, analisou-se a ação e interação do projeto pequi vivo com os moradores do Sítios Cruzeiro e Jatobá.

A contribuição dessa pesquisa se dá com a demonstração dos desafios da sustentabilidade em uma comunidade rural e as mudanças ocorridas na mesma durante a ação de um projeto de extensão premiado que interferiu a vida dos moradores de uma comunidade rural. Desde o início da revolução industrial onde os habitantes da zona rural viram uma possibilidade de crescimento abandonando o campo, e migrando para as cidades surgia a crença de que para haver crescimento pessoal e emprego era necessário ir para a zona urbana.

A ausência de políticas públicas na zona rural como modelo de crescimento econômico, também fortifica esse pensar de que só existe trabalho e renda na zona urbana, mesmo sabendo que na chapada do Araripe existe um fruto sazonal, o pequi, que tem um grande poder de comercialização, porém tem perecibilidade alta, este fato contribui para a comunidade em tempos de coleta, devido ao excedente, desperdice o fruto, enterrando ou até queimando, por não haver formas de armazenamento e comercialização, em tempos de safra a desvalorização do fruto é muito grande.

A implementação de um galpão de beneficiamento de pequi, para armazenar este fruto congelado para posterior comercialização parece ser uma forma de melhorar a qualidade de vida da comunidade evitando o desperdício do fruto, mas essa ação traz consigo uma serie de implicações culturais, sociais, ambientais e econômicas, dos desafios da sua implementação ao seu funcionamento, sendo esse um dos objetos de estudo dessa pesquisa. 
Os desafios da sustentabilidade na territorialização das comunidades rurais e sua estruturação a partir de uma organização, sendo está baseada em um outro tipo de economia conforme denomina Singer (2010), como está acontecendo na comunidade em estudo, para desenvolver um galpão de beneficiamento de pequi na zona rural, sitio Cruzeiro e Jatobá, Crato, são muitos: a distância do meio urbano, os meios de comunicação pouco acessíveis, a tecnologia, o trabalho em grupo, as crenças da comunidade, por experiências anteriores, e até a implementação dos insumos básicos para o funcionamento como água e energia; visto que antes do início da construção do galpão, a água da comunidade era proveniente de cisternas de placas, com captação de águas da chuva e a energia necessária para o funcionamento do galpão deve ser trifásica.

A constituição dessa dissertação está constituída por sete tópicos distribuídos conforme o texto a seguir. A Introdução fora constituída por elementos que fundamentam e justificam esse estudo como também estão descritos os objetivos gerais e específicos e a relevância desse estudo para a autora e sua contribuição para a sociedade.

O capítulo primeiro está composto pelo referencial bibliográfico que dá suporte a pesquisa em questão: Inicia-se com um texto sobre a evolução histórica das questões ambientais, do início da pré-história até as questões atuais, abrindo uma ênfase na década de 70 onde surgiram os primeiros questionamentos sobre as questões ambientais e a construção do termo desenvolvimento sustentável com a Comissão de Bruntdland, aprofundando a discussão com Sachs, Burstyn e Chacon, com o discurso sendo palavras que precisavam de mais efetividade e as dimensões da sustentabilidade propostas por Sachs e Dias, conseguem dar o suporte teórico para o desenvolver desse estudo.

O capitulo dois discorre sobre os objetos de estudo que são as comunidades rurais e como estas vivem as dimensões da sustentabilidade e o fruto pequi (Caryocar) que foi eleito por essa comunidade como a principal fonte de renda depois dos benefícios sociais, bolsa família e aposentadoria. No capítulo três mostra-se o caminho percorrido para a construção desse estudo, descreve-se: o local da pesquisa e os sujeitos que participaram; os instrumentos e procedimentos de coletas de dados, discorre-se sobre o processo de conhecimento e da comunidade participante da pesquisa e a relação com a autora, as visitas e acompanhamento dos processos da comunidade como também as ações sobre ela.

O capítulo quatro relata os resultados da pesquisa e a triangulação dos dados com autores renomados, e as respostas dadas pela comunidade sobre as dimensões da sustentabilidade. O capítulo cinco descreve o projeto pequi vivo, por se tratar da segunda principal fonte de renda dessa comunidade e entender que através desse projeto as dimensões da sustentabilidade conseguem serem visualizadas. $\mathrm{O}$ capitulo seis relata as considerações finais desse estudo.

\section{REVISÃO TEÓRICA}

\section{Evolução histórica das questões ambientais}

Desde os tempos mais remotos em busca de melhores condições de sobrevivência, o homem 
começou a modificar o ambiente natural a fim de adaptá-lo, e por possuir essa capacidade, vive no deserto, no frio das calotas polares ou nas florestas; e utilizando-se dos recursos naturais, começou a produzir ferramentas, criar animais cercados, viver em grupo e tudo que viesse a suprir suas necessidades, afirma Dias (2011).

O mesmo autor complementa ainda que a partir da primeira revolução cientifica tecnológica foram provocados os grandes impactos ao meio ambiente, as grandes concentrações da espécie humana em locais específicos, ocorrendo assim a ocupação dos espaços naturais intensificando gradativamente a destruição do ambiente natural, ressalta também que, quanto maiores as aglomerações humanas, mais destrutivas tornavam-se do ponto de vista ambiental, recriando o ambiente, assim os outros organismos vivos também passaram a conviver nos mesmos espaços, como pragas e microrganismos que transmitem doenças; porém um dos problemas mais notórios causados pela industrialização, é a destinação dos resíduos de qualquer tipo, que sobram do processo produtivo, que afetam o meio ambiente natural e a saúde humana,

Dias (2011) ainda complementa relatando sobre o resultado de um relatório elaborado pela defensoria das águas afirmando que a principal fonte de contaminação no país é o despejo de material tóxico proveniente das atividades industriais, e que essas junto com as atividades agroindustriais são responsáveis pelo consumo de $90 \%$ das águas e que essas são devolvidas a natureza contaminadas após o uso. Confirma assim Barbieri (2011) afirmando que foi a partir da revolução industrial que surgiram os problemas ambientais de maior escala, poluindo o ar, as águas e o solo que afetam a qualidade de vida das pessoas e comprometem a sobrevivência humana.

Desde a revolução industrial percebe-se o aumento crescente dos sistemas produtivos e consequentemente poluição de todos os tipos e em todos os setores: indústria, comércio e serviços. Jimenez et al. (2009) afirmam que estes problemas se intensificaram nesse período e trouxe consigo agressões cada vez maiores para a natureza. Assim, as discussões sobre o meio ambiente surgem nos anos 70 em forma de encontros internacionais para reflexão sobre a utilização dos recursos naturais, daí apareceram os primeiros instrumentos de comando e controle como a legislação ambiental e as secretarias de meio ambiente. Esse fator pressiona as empresas a cuidarem melhor das suas relações com a sociedade e a natureza, sendo exigência dos mercados e dos governos.

Segundo Bursztyn (2007) o Brasil teve uma industrialização tardia, e trouxe condições particularmente perversas, como: pobreza, miséria, desigualdade e degradação ambiental, isso ainda afirma o autor é consequência da falta de um sistema de mudança técnica, e diz que essas economias não conseguiram sobreviver, se não pudessem extrair competitividade da exploração predatória de seus recursos naturais e humanos.

Barbieri (2011) e Valle (2004) concordam que nos anos 90 as necessidades ambientais já estavam bastante popularizadas, surgiram então novos conceitos na área, e nessa década as comunidades internacionais visualizaram o surgimento das normas internacionais de qualidade da International Organization for standardization (ISO 9000) e, por conseguinte, as normas ISO 14000 referentes à qualidade ambiental. Os mesmos autores revelam que em 1992 aconteceu na cidade do Rio de Janeiro a Conferência 
das Nações Unidas para o meio ambiente e desenvolvimento sustentável, onde levantou-se discussões acerca das ações contra o meio ambiente que não são isoladas, mas trazem consequências globais.

Diante dessas discussões surge essa nova ordem chamada sustentabilidade, para que as gerações futuras possam usufruir da mesma qualidade de vida atual, Percebe-se portanto, que a busca pelo lucro incessante tem destruído o que há de humano nas pessoas, para tanto afirma Chacon (2007) que diante de uma sociedade que cria indivíduos que se julgam suficientes o bastante para esquecer seus semelhantes e a natureza, destrói o meio ambiente gerando desigualdades e cabe perguntar: O que é ser humano afinal?. Thomas Hobbes citado por Dias (2011) complementa que o homem sem predadores se tornou o lobo de si mesmo.

\section{Desenvolvimento sustentável}

Para a compreensão da construção do conceito de desenvolvimento sustentável destaca-se a a afirmação de Demajorovic (2006) que diz que o modelo de produção utilizado no século XX despertou para algumas premissas e percepções sobre a capacidade ilimitada do planeta terra e que este seria uma fonte inesgotável de matéria primas, e considerou que a produção de poluentes e resíduos seria inevitável; as possibilidades de esgotamento de alguns recursos naturais começam a ser percebidos ao longo das décadas 1950 e 1960. Se fortalecendo nos anos 70, associados a alguns desastres ambientais causados pela ação humana, que acabou desencadeando um movimento de cunho ambiental mais amplo que culminou no lançamento do livro primavera silenciosa pela bióloga Rachel Carson, em 1962, considerado um marco ao detalhar os efeitos da contaminação ambiental decorrente da má utilização dos pesticidas e inseticidas químicos sintéticos, essa obra gerou revolta e manifestações na sociedade (PHILIPI JR. et al., 2014).

Em 1972, coma realização da Conferência de Estocolmo capital da Suécia, surgiu o conceito de desenvolvimento sustentável, que até então era conhecido como 'Ecodesenvolvimento', esse termo foi proposto por Maurice Strong e em seguida ampliado por Ignacy Sachs, que além da preocupação com o meio ambiente, incorporou as devidas atenções as questões sociais, econômicas, culturais, de gestão participativa e ética afirma Dias (2011).

Ainda de acordo com Dias (2011), após a Conferência de Estocolmo, a Assembleia Geral das Nações Unidas, gerou um plano mundial, formada por uma comissão de 21 países e presidida por Gro Harlem Brundtland, primeira ministra da Noruega, que materializou em um documento considerado um dos mais importantes sobre questões ambientais, chamado de Nosso Futuro Comum, também conhecido como relatório de Brundtland, relata orientações cujo principal objetivo é a preservação e a melhoria no ambiente humano, veiculando economia e ecologia de forma estreita, formalizando assim o conceito de desenvolvimento sustentável, que prevê a integração entre economia, sociedade e meio ambiente onde Valle (2004) complementa e confirma com Dias (2011) o conceito discutido na comissão de Brundtland que era o de suprir as necessidades das gerações presentes sem comprometer que as gerações futuras usufruam da mesma qualidade de vida, das gerações atuais. 
Segundo Dias (2011) O relatório produzido pela Comissão de Brundtland define além das premissas para o Desenvolvimento Sustentável as políticas ambientais e desenvolvimentistas, que em síntese são: Retomar o crescimento, e consequentemente alterar a qualidade do desenvolvimento; Atender as necessidades essenciais de emprego, alimentação, energia água e saneamento; Manter um nível populacional sustentável; Conservar e melhorar as bases de recursos e reorientar a tecnologia para administrar os riscos; Incluir ao meio ambiente e a economia no processo de tomada de decisões.

Dias (2011) ainda afirma que dessas orientações surgiram várias interpretações, onde diferentes grupos sociais sintetizaram com o seu olhar as propostas de sustentabilidade do relatório em questão, embora se difundam algumas visões pessimistas, dentro da generalidade com que foi exposto pelo documento da Comissão de Brundtland, essa discussão, apesar de ambiguidades e mal entendidos, abriu muitos questionamentos sobre equidade social dentro de uma mesma geração e inseriu definitivamente o meio ambiente nos debates sobre desenvolvimento de forma definitiva.

Para alguns o desenvolvimento sustentável é um movimento político econômico para erradicar a pobreza com projetos sociais, para outros são orientações para o desenvolvimento harmônico da sociedade, considerando a apropriação e a transformação sustentável dos recursos naturais, trata-se somente, segundo alguns, de uma forma de deixar compatível o meio ambiente com o crescimento econômico contínuo, mantendo as condições que produzem e reproduzem as relações de exploração, hierarquização e dominação que permitem a apropriação da capacidade produtiva social por alguns homens, e para outros, implica novas bases, nas quais se sustenta a civilização, através de uma nova racionalidade ambiental que tenha como objetivo da organização social produtiva o bem estar material do ser humano e sua qualidade de vida (DIAS 2011).

Chacon (2007) afirma que o desenvolvimento sustentável virou moda e um discurso ou plano político, a palavra sustentabilidade, ainda que desgastado pelo uso exacerbado deu uma nova tonicidade as questões sócias ambientais e proporcionou novas perspectivas para as populações carentes, especialmente as que moram no semiárido nordestino, o discurso de seca passou a ser convivência com o semiárido.

Várias reuniões foram realizadas, destacando-se a de 1997, no Japão, que originou a criação do Protocolo de Quioto, estabelecendo metas de redução da emissão de gases de efeito estufa na atmosfera a serem cumpridas até 2012, usando como referência as emissões de 1990. Os Estados Unidos da América não assinaram o tratado alegando que o mesmo comprometeria seu crescimento econômico afirma (REIS, 2012).

Segundo Pereira (2011) em 1997 a ONU promoveu a Rio + 5 no Rio de Janeiro e em 2002 a Rio +10 em Joanesburgo, reuniões que tinham como finalidade discutir os resultados da agenda 21, que foi o documento resultante da Rio 92, concluiu-se que os resultados da agenda 21 foram poucos e constatou-se a necessidade de adotar ações mais eficazes e enérgicas capazes de operar transformações econômicas, políticas, sociais e culturais para o novo modelo de desenvolvimento sustentável.

Nesse contexto, Pereira (2011) faz um comentário e associa o termo sustentabilidade "[...] à crescente conscientização de que os países precisam descobrir, novas maneiras de promover o crescimento 
de suas economias, sem destruir o meio ambiente, prejudicar a qualidade de vida da sociedade ou sacrificar o bem-estar das futuras gerações".

Dias (2011) complementa afirmando que as discussões foram significativas e promissoras, embora existam ambiguidades e mal-entendidos sobre o termo desenvolvimento sustentável, as portas ficaram abertas para o debate da equidade social dentro de uma mesma geração e colocou o meio ambiente dentro do debate de desenvolvimento de forma definitiva.

A sustentabilidade em sua essência remete a ideia de justiça e auto consciência, pois tudo aquilo que por meio de ação traz impactos negativos para o ecossistema e as futuras gerações são consideradas insustentáveis, na sua forma pura e elementar a sustentabilidade refere-se a necessidade de sobrevivência de um ser vivo a longo prazo, visto que a sobrevivência é dita por depender de vários fatores como água, ar solo e alimentos, que são essenciais para a sobrevivência de espécies, inclusive o ser humano, isso seria a regra básica da existência humana: Manter a sustentabilidade nas condições de vida que depende (BOSSELMAN, 2015).

Para Barbosa (2008), o desenvolvimento sustentável não é um estado fixo de harmonia, mas sim um processo de mudança, no qual se compatibiliza a exploração de recursos, o gerenciamento de investimentos tecnológicos e as mudanças institucionais com o presente e o futuro, para ser alcançado o desenvolvimento sustentável dependem de fatores básicos como o planejamento e principalmente o reconhecimento da finitude dos recursos naturais, todavia não pode nunca condir os termos crescimento e desenvolvimento, pois o crescimento está associado ao consumo crescente de água energia e outros recursos naturais, o desenvolvimento nesse aspecto é insustentável, acarretando esgotamento ou escassez desses recursos aos quais toda a humanidade depende.

Veiga (2010) parte da premissa que o desenvolvimento econômico está frequentemente sendo conceituado como sinônimo de crescimento, pois era o termo mais utilizado para conceituar o desenvolvimento, e que por isso gerou várias discussões para os analistas; é de fundamental importância compreender esses conceitos pois envolve recursos naturais renováveis e que se não forem gerenciados de forma adequada e com consciência implica em impossibilidades para as futuras gerações. Para Veiga (2010), o desenvolvimento pode ser entendido como sinônimo de crescimento econômico, e que pode ser mensurado pelo produto interno bruto per capita. Porém ainda afirma que quando o Programa das Nações Unidas para o Desenvolvimento PNUD lançou o Índice de Desenvolvimento Humano IDH, compreendeu que o desenvolvimento não poderia mais ser sinônimo de crescimento econômico, pois não havia uma identificação.

Segundo Veiga (2010) com a publicação do relatório de Desenvolvimento Humano de 1990, a definição de desenvolvimento como sinônimo de crescimento já não faz mais sentido, pois o objetivo do relatório era desmistificar essa crença e enfatizar que o desenvolvimento passava a ser visto como a busca da paz e assim o crescimento já não era mais o sinônimo de crescimento, passando a ser compreendido como um processo maior, visto que resultados não era sinônimo de benefícios. 
Dias (2010), afirma que até então não se tinha necessidade de fazer a distinção entre os termos em discussão, pois poucos países haviam enriquecido na época da industrialização, porém os que eram subdesenvolvidos ainda continuavam pobres, onde a industrialização não tinha iniciado. Então Veiga (2010) ressalta que até então o crescimento ocorrido em 1950 em vários países não havia um maior acesso pelas pessoas de classe baixa e a bens materiais como foi observado em países desenvolvidos, onde a iniciativas começaram pelo acesso a saúde e educação.

A partir dessas reflexões de Veiga (2010) conclui que o verdadeiro sentido sobre o conceito de desenvolvimento começou a entrar em debate, a ONU defendia e divulgava índices de desenvolvimento que não estava atrelado necessariamente a uma renda per capita.

\section{Dimensão Social}

Sachs (2000), ao trazer o conceito de desenvolvimento sustentável, afirma que esse deve transcender o significado econômico, estando em conformidade com cinco dimensões: a social, a econômica, a ecológica, a espacial e a cultural, Dias (2011) ressalta apenas três: a Econômica, a Social e a ambiental por entender a sustentabilidade como um tripé.

A dimensão social refere-se a busca de igualdade de condições, tem base no pressuposto Crescer para o benefício de quem?. Essa questão vem com a reflexão de Wofgang Sachs (2000) quando ele fala sobre a fome, o desemprego, as desigualdades, discriminações e que associa esses aspectos ao desenvolvimento sustentável afirmando que as dimensões precisam se transversalizar, a Cultura, a economia, o social, e os territórios, para haver uma ação afirmativa dos atores locais para a construção de políticas sustentáveis

\section{Dimensão Econômica}

Sachs (2002) escreve sobre a dimensão econômica afirmando que é aquela que possibilita um gerenciamento intersetorial equilibrado, utilizar de forma eficiente consciente os recursos naturais, e buscar através de investimentos públicos e privados o desenvolvimento sustentável com segurança alimentar e capacidade de modernização contínua dos instrumentos de produção e autonomia na pesquisa científica e tecnológica sem ter o foco nesse aspecto mas agindo para que essa seja a consequência das ações. E afirma também que a dimensão ecológica e ambiental é sem dúvidas uma das mais importantes, sendo ela caracterizada pela compreensão e respeito nas práticas do meio ambiente. Pois exige a reflexão que o ser humano não é dono do meio ambiente, ele apenas o utiliza, o ser humano é apenas parte integrante e dependente dele. Ainda nessa dimensão é notável as medidas tomadas para a conservação do potencial do capital natural.

Ocorre que, num determinado momento, estudos demonstraram que a natureza não estava suportando sua exploração e que muitos dos recursos utilizados em breve deixariam de existir. O alarme causou uma mobilização continuada, que desembocou numa nova proposta de desenvolvimento que contempla o meio ambiente natural, que deveria ser preservado para a utilização futura pelas novas gerações (DIAS, 2011). 
Por essa transversalidade e intersecção entre os termos crescer e desenvolver é que Bursztyn (2007), discorre sobre esse tema salientando as suas diferenças e importâncias, afirmando que não há desenvolvimento se não houver qualidade de vida e equilíbrio com a natureza.

\section{Dimensão territorial (espacial)}

Sachs (2002) relata que a dimensão espacial se refere a organização do espaço, na busca de gerenciar e projetar a configuração rural- urbana mais equilibrada e uma melhor distribuição territorial de assentamentos urbanos e atividades econômicas, como, reduzir a concentração excessiva nas áreas metropolitanas, impedir a destruição de ecossistemas, criar uma rede de reservas naturais e de biosfera, para proteger a biodiversidade.

Santos (1988) traz que a temática do espaço habitado pode ser considerada tomando dois pontos de vista: o biológico, "pelo reconhecimento da adaptabilidade do homem, como indivíduo, às mais diversas altitudes e latitudes, aos climas mais diversos, às condições naturais mais extremas". Partindo do ponto que o ser humano não pode mais ser visto como indivíduo isolado, mas como um ser social por excelência, portanto, acompanhando expansão e distribuição, bem como mudanças demográficas e sociais dos seres humanos, assim conclui: "O fenômeno humano é dinâmico e uma das formas de revelação desse dinamismo está, exatamente, na transformação qualitativa e quantitativa do espaço habitado". Este dinamismo podendo ser visível nos territórios brasileiros.

Nas palavras de Pasqual et al. (2008) historicamente, a concepção de território associa-se a ideia de natureza e sociedade configuradas por um limite de extensão do poder. Contemporaneamente, fala-se em complexidades territoriais, entendendo território como campo de forças, ou "teias ou redes de relações sociais". Contribuindo com a temática Raffestin (1993) afirma que o território se forma a partir do espaço, sendo como resultante de uma ação conduzida por um ator que realiza um programa em qualquer nível, neste sentido, o ator territorializa o espaço ao se apropriar do mesmo quer concreta ou abstrata. Nesta vertente Haesbaert (2002), identifica uma multiterritorialidade reunida em três elementos: os territórioszona - prevalecendo a lógica política, os territórios-rede - prevalecendo a lógica econômica e os aglomerados de exclusão - ocorrendo uma lógica social de exclusão sócio-econômica das pessoas.

Por fim, observa-se que o espaço adota atualmente uma importância fundamental, visto que a natureza se transforma ao seu todo, numa forma produtiva. Assim sendo, quando de maneira direta ou indireta todos os lugares forem atingidos pelas necessidades do processo produtivo "criam-se, paralelamente, seletividades e hierarquias de utilização com a concorrência ativa ou passiva entre os diversos agentes. Donde uma reorganização das funções entre as diferentes frações de território". Com isto, pode-se dizer que "cada ponto do espaço se torna então importante, efetivamente ou potencialmente. Sua importância decorre de suas rias virtualidades, naturais ou sociais, preexistentes ou adquiridas segundo intervenções seletivas" (SANTOS, 1988). 


\section{Dimensão Cultural}

Para Leff (2009), toda formação social desenvolve-se numa estreita relação com os eu entorno natural. Quando entende-se essa relação entre a população humana e o meio ambiente habitado, não tem como resultado apenas uma adaptação biológica, a dinâmica do capital sobre os ecossistemas , e a não racionalidade no uso dos recursos naturais está sempre condicionada por práticas culturais tradicionais e a racionalidade ecológica ou não dessas práticas não associam-se apenas a técnica e sim aos processos simbólicos culturais, e nessa construção os conhecimentos tradicionais em muitos casos geraram práticas de manejo sustentável de recursos, ou não.

Daí afirma Leff (2009) a importância de investigar a organização social e produtiva das culturas tradicionais das comunidades e sociedades do campo para conhecer e revalorizar o processo histórico de assimilação cultural dos processos ecossistêmicos. Sachs (2002) ainda comenta sobre a dimensão cultural dizendo que essa pode ser entendida pela valorização da história, cultura e das tradições de um lugar, na busca de preservar, divulgar e investir construindo uma sociedade com base no desenvolvimento sustentável

\section{Dimensão Ecológica}

Segundo Sachs (2000) os critérios ecológicos estão relacionados a preservação dos recursos naturais, com a finalidade de diminuir o uso de combustíveis fósseis, além da atenuação de substâncias poluentes, Dias (2011) acrescenta que é importante para todo ser humano uma cultura ambiental, donde se busca a conscientização de todos para a não poluição de qualquer ambiente natural.

\section{Dimensão Política}

Segundo Barbieri (2011) os problemas ambientais passaram a ser tratados de forma sistemática após a revolução industrial, e mesmo assim os governos agiam de forma corretiva com relação as questões ambientais, e a partir da década de 70 começaram a surgir em vários países políticas governamentais que tratavam das questões ambientais; entende-se por uma política pública ambiental o conjunto de diretrizes , objetivos e instrumentos de ação que o poder público dispõe para produzir efeitos desejáveis no meio ambiente através dos instrumentos explícitos e implícitos.

Entende-se que, para a dimensão política da sustentabilidade se realize, seja necessário um planejamento e uma integração de ações nas outras dimensões, para Barbieri (2011) a eficácia de alguns instrumentos explícitos de política ambiental depende de outros instrumentos de outras políticas públicas; porém com frequência ocorre o contrário, há uma convivência antagônica entre diversas políticas públicas. Por exemplo uma política agrícola voltada para a produtividade pode induzir o uso abusivo de água, fertilizantes e agrotóxicos; a ausência de uma política de transporte coletiva nas grandes cidades implica no uso do transporte individual e por consequência na qualidade do ar. 


\section{O fruto do cariri: pequi caryocaraceae, gênero caryocar coriaceum witth}

Segundo Silva et al., (2006) e Matos (2007), o pequi pertence a família Caryocaraceae, gênero Caryocar coriaceum witth.; engloba cerca de vinte espécies. Este é um fruto típico da Chapada do Araripe, e percebe-se a importância social e econômica das atividades que envolvem o cultivo, coleta transporte e comercialização do mesmo. O uso de matérias primas de origem extrativista está condicionado a sazonalidade do produto, a frutificação do pequi é anual e irregular entre safras, e as comunidades rurais que dependem financeiramente desse cultivo precisam ser orientadas para explorar o fruto em sua totalidade, pois aproveita-se em sua maioria apenas o fruto, e sabe-se que o aproveitamento vai além do fruto, como a castanha, a extração do óleo de pequi, molhos entre outros. O pequizeiro da espécie Caryocar coriaceum Wittm. é uma planta arbórea, pertencente à família Caryocaraceae. Apresenta tronco grosso com até dois metros de circunferência e 12 a 15 metros de altura, revestido de casca escura, com galhos grossos, compridos e inclinados. Tem folhas opostas com folíolos ovais, verde-luzentes. As flores com coloração amarelo intenso e estames vermelhos são grandes e estão reunidas em cachos terminais. O fruto (pequi) é globoso, do tipo drupóide, formado por um epicarpo (casca) verde-amarelado, que recobre de um a quatro pirênios, conhecidos como caroços; o mesocarpo oleaginoso divide-se em externo (coriáceo carnoso) e interno (parte comestível amarelo-carnoso ou polpa), envolvendo o endocarpo lenhoso com espinhos delgados e agudos, sob o qual está a amêndoa branca ou semente, carnosa e também oleaginosa. O conjunto mesocarpo interno, endocarpo espinhoso e semente constituem o pirênio (SILVA et al., 2006; MATOS, 2007).

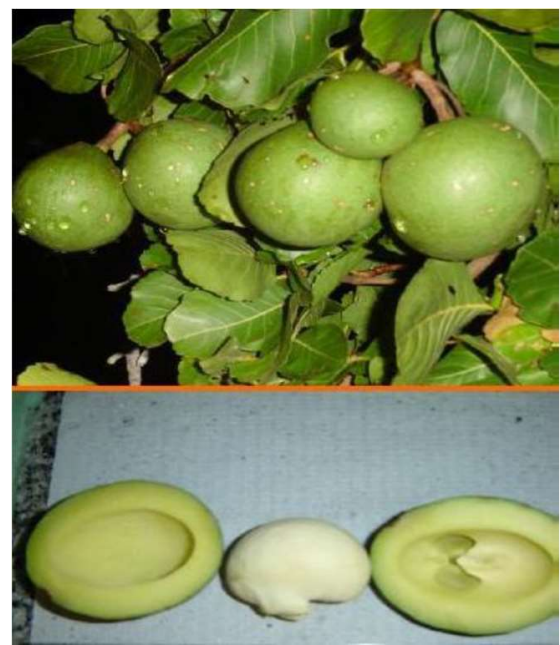

Figura 1: Fruto de Caryocar coriaceum Wittm. Fonte: Oliveira et al. (2008).

O pequizeiro exerce importante papel socioeconômico na Chapada do Araripe e sertões vizinhos do Ceará, Pernambuco e Piauí. A polpa e amêndoa do pequi são altamente nutritivas e constitui-se em valioso recurso alimentar para a população dessas regiões. A principal utilização do fruto é o consumo direto do "caroço" (OLIVEIRA et al., 2008), óleo da amêndoa é utilizado na medicina popular, juntamente com mel de abelha, no tratamento de enfermidades como gripes, bronquites e infecções bronco-pulmonares, configurando assim um importante recurso na farmacologia popular (BRAGA, 1960; AGRA et al., 2007). 


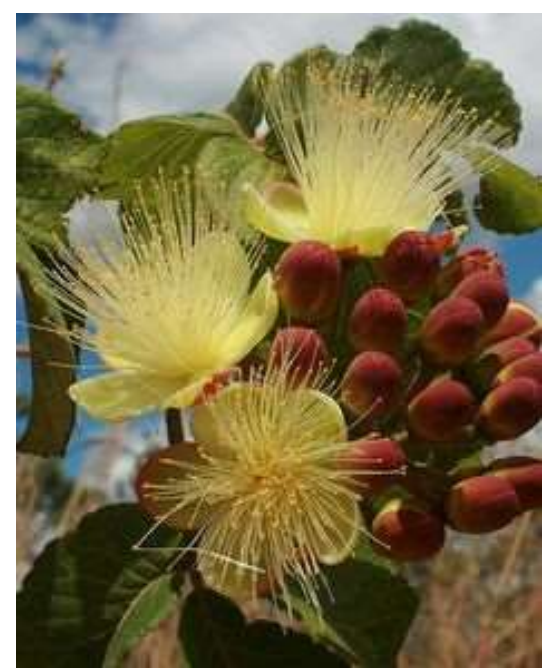

Figura 2.

No período da safra, que ocorre entre dezembro e abril, no Ceará, famílias inteiras da região do Cariri deixam suas casas e sobem à Chapada do Araripe para o trabalho de coleta dos frutos e extração, por fervura em água, do óleo de pequi, obtido da polpa do fruto, para comercialização ou para própria alimentação. 0 óleo é negociado nas feiras e casas de comércios da região, sendo adquirido geralmente para fins medicinais e culinários. Ao fim da safra, grande quantidade de amêndoas (sementes) é deixada no local ou também submetida à extração de óleo (MATOS, 2007).

A maioria das informações disponíveis na literatura refere-se à espécie $C$. brasiliensis, as quais auxiliam na compreensão das características e propriedades de $C$. coriaceum, em virtude da proximidade genética entre essas duas espécies (OLIVEIRA et al., 2008). A análise da composição química de $C$. brasiliensis revelou que a polpa apresenta alto teor de umidade $(41,50 \%)$, além de lipídios $(33,4 \%)$, carboidratos (11,45\%), fibras (10,0\%) e proteínas (3,0\%). A amêndoa, por sua vez é rica em lipídios (51,51\%), apresentando em sua composição proteínas $(25,27 \%)$, carboidratos $(8,33 \%)$, fibra alimentar $(2,2 \%)$ e baixo teor de umidade $(8,68 \%)$ e elevado teor elevado de minerais representado pelas cinzas (4,0\%) (LIMA et al., 2007). A polpa e semente do pequi representam apenas $25 \%$ do fruto. Embora o epicarpo (casca) represente a maior parte do pequi (75\%), há poucos estudos sobre esta parte do fruto, provavelmente por ser um resíduo rejeitado pela população (ROESLER et al., 2007).

\section{Desenvolvimento sustentável nas comunidades rurais}

Segundo Chacon (2007) a imagem do sertão foi sempre associada a seca, a pobreza e a dependência e isso parece ter estabelecido uma concordância de que o rural, os sítios e as comunidades rurais precisam sempre estar associadas a conchavos, lutas e conflitos nessa arena onde as alianças políticas que se aproveitam da situação ambiental de determinadas regiões ficam descortinando-se os interesses e a manipulação para que os detentores do capital sempre permaneçam na liderança das ideologias.

Segundo Leff (2009) A implantação de modelos econômicos tecnológicos e culturais ecologicamente inapropriados durante a dominação colonial e agora no capitalismo gera uma irracionalidade produtiva, no 
sentido de exploração do manejo ecológico ineficiente que enaltece a exploração dos recursos naturais e o enriquecimento de poucos.

Segundo Leff (2009) O desenvolvimento rural caracterizou-se por grandes diferenças na sua organização produtiva: ao lado de modernas empresas agrícolas, o desaparecimento de grande parte do setor de subsistência provocou uma subutilização dos recursos naturais e culturais; Um grande número de pequenos produtores habitantes da zona ruralestão desempregados, subempregados, produzindo em condições que não lhes permitem suprir suas necessidades básicas. Os preços de seus produtos são cada vez mais desfavoráveis em relação aos insumos produtivos, ou na força de trabalho e tempo dispendidos na coleta dos frutos da floresta a serem comercializados, o mesmo autor ainda reflete que esse modelo de desenvolvimento econômico produziu desequilíbrios nacionalmente e regionalmente, gerando efeitos de desintegração cultural e ecológica; pregando principalmente que o desenvolvimento estaria na zona urbana e ficar na zona rural seria um atraso de vida, o processo de industrialização urbana traz consigo uma ideia de transferência de valor do campo para a cidade, a transculturação tecnológica gera degradação dos ecossistemas, e desuso das práticas tradicionais das comunidades rurais e a destruição das forças culturais de produção da sociedade.

O processo de transculturação para Leff (2009) fez com que se perdesse muito do saber das comunidades impondo o saber técnico científico, muitas vezes sem absorver o conhecimento empírico da vida das sociedades tradicionais. Esta visão do Desenvolvimento sustentável integra a socialização entre a natureza e os potenciais ecológicos e estes levam ao aparecimento de novos movimentos sociais nas áreas rurais.

Diante dessas discussões entre o urbano e o rural o que se percebe é o enriquecimento de poucos e empobrecimento de muitos e surge então segundo os estudos de Singer (2010) a economia solidária originou-se depois do capitalismo industrial, como resposta ao empobrecimento dos artesões provocado pela difusão das máquinas e fábricas. Mesmo em meio a tanta exploração do trabalho de homens, mulheres e crianças com jornadas de trabalho intensas, surgia um homem chamado Robert Owen, que limitou a jornada de trabalho e mostrou que essa forma de trabalhar gerava lucros.

Singer (2010) afirma que a economia solidária é outro modo de produção, cujos princípios básicos são a da propriedade coletiva ou associada do capital e o direito a habilidade individual, esses princípios na prática se, traduzem em: classe trabalhadora que são os possuidores de capital por igual que difere do capitalismo onde existe a competição entre os detentores da propriedade do capital e os que vendem a força de trabalho; o resultado natural desse segundo modo é a competição e a desigualdade enquanto que o resultado natural da economia solidária é a solidariedade e a igualdade.

Ainda sob os estudos do mesmo autor afirma-se que a economia capitalista fortalece a heterogestão e a competição exagerada, com poder centralizado onde o detentor do capital e dos bens tem o poder; enquanto que na economia solidária prevalece a auto-gestão, as decisões são tomadas em assembleias quando estas têm um número reduzido de pessoas, e em grupos maiores através de representações e votações. 
Segundo França Filho et al. (2004) somos habituados a pensar a economia de forma mercantil, processo de troca de objetos, por dinheiro deixando o capitalismo como única forma de reger a economia, sem admitir a possibilidade de fazer outro modo de economia, os autores enfatizam outras formas de reciprocidade, que alimentam relações econômicas não monitorizadas que permitem uma forma de sobrevivência diferente a uma parcela significativa da população, em diversas partes do mundo;

Os mesmos autores relatam que a solidariedade, afirmada como uma ação voluntária, das pessoas, quando realizadas em espaços públicos é desenvolvida uma dinâmica no planejamento das atividades comunitárias relacionando muitas vezes problemas públicos mais gerais, como por exemplo: Cultura, meio ambiente e educação; entende-se pois que essa outra economia, assim denominada combina uma dimensão comunitária tradicional com a dimensão pública, essa ação é evidenciada quando surgem as associações fortemente baseadas nos vínculos comunitários.

Chacon (2007) afirma que o ser ou não ser sertanejo, estar ou permanecer na zona rural, é uma questão que se coloca hoje com persistência, especialmente para os jovens que não veem no sertão as oportunidades que almejam. Percebe-se também que a rápida entrada dos meios eletrônicos no sertão no sertão tem modificado o sertão trazendo um turbilhão de informações sobre um modo de vida estranho a esse lugar.

\section{Comunidades rurais}

Os problemas ambientais acumulam-se, e a ciência e tecnologia são aplicadas como solução há quase tudo, embora Barbierí ( 2008) afirme que a ciência e tecnologia são causa dos problemas e também solução, percebe-se a economia passando a ser o único horizonte de felicidade dos povos e assim surge um mal-estar social e moral afirma Zaoual (2010) pois a sociedade perde a razão de ser, assim diante dessa afirmação, o retraimento comunitário se torna uma das soluções para muitos grupos da população a qual se encontram. Zaoual (2010) ainda afirma que o homem precisa crer pertencer a algo e ser integrado, quando o lugar que ele ocupa não o oferece mais conteúdos simbólicos, ele tende a procura-lo em outros ambientes ou transformar o seu ambiente em outro que o signifique como afirma Bursztyn (2008) quando fala que a distinção entre zona urbana e rural é um polêmico tema da atualidade, a caracterização das comunidades rurais realizava-se pela leitura de um lugar de difícil acesso, casas de taipa, ausência de veículos mecanizados, a escola do campo, ausência de energia elétrica e água encanada, porém a realidade atual da zona rural é bem diferente, extinguiram - se as casas de taipa, sendo estas substituídas por habitações de alvenaria com suas antenas parabólicas, o acesso melhorou, as casas estão mais próximas umas das outras, e as bicicletas e motocicletas substituem gradativamente, os jumentos e carroças, a energia elétrica, passou a ser essencial nas comunidades rurais, ocorre também a mudança das cacimbas por cisternas de placas.

Bursztyn (2008) relata que o novo sertão é urbano, o campo foi perdendo população para os centros urbanos e grandes capitais, os vilarejos são hoje maiores e mesmo pequenas aglomerações que antes representavam apenas núcleos de casebres de famílias de trabalhadores rurais, agora sobrevivem graças a outras fontes de renda. 
O homem só se sente bem segundo Zauoal (2010) quando encontra seu lugar, seu sítio, esse imperativo existencial não é atendido pelo mercado, essa necessidade escapa as ciências racionais e econômicas que permanecem dominadas por valores utilitaristas e mercantis e não levam em conta as múltiplas dimensões da existência humana como: Identidade, cidadania, ajuda mútua, solidariedade e qualidade de vida.

A ausência de políticas públicas de fixação e incentivo ao homem do campo faz com que este não se sinta pertencente ao seu lugar, ser importante, pertencer a algum lugar, uma sociedade, um local, quando o ser humano pertence a um espaço e/ou território ele cria vínculos um 'sítio' simbólico de pertencimento afirma Zaoual (2010), complementa também que a sociedade complexa aparenta um apartheid territorial, um modelo socialmente fragmentado, em um mesmo território, existe o situs do que tem o poder e o situs do marginalizado.

Segundo Leff (2009) as transformações geradas pelo processo de exploração do capital, sepulta de alguma forma uma enorme quantidade de conhecimento prático elaborado pelas comunidades destas regiões rurais, que se permitiam muitas vezes um uso mais sustentável dos potenciais naturais e de seus territórios. Percebe-se que o capitalismo rompeu o equilíbrio entre os sistemas naturais e as formações sociais.

\section{METODOLOGIA}

\section{Tipo do estudo}

A pesquisa foi a princípio construída de um referencial teórico com os principais autores da temática sobre comunidades rurais, por ser o centro desse estudo, o desenvolvimento sustentável desde o início da expressão que se deu por volta da década de 80 e alguns temas adjacentes para subsidiar a pesquisa. Caracterizada como uma pesquisa básica, que segundo Severino (2016) é aquela que tem o objetivo de gerar o conhecimento com a finalidade de contribuir com o avanço científico, envolvendo verdades e interesses gerais; com o intuito de relacionar os conceitos de desenvolvimento sustentável em suas principais dimensões como os conceitos universais, relacionando esses conceitos com a realidade das comunidades rurais para contribuir cientificamente.

Utilizou-se para o tratamento dos dados coletados uma abordagem qualitativa, que de acordo com Severino (2016) enfatiza a perspectiva do indivíduo ou grupos de indivíduos em estudo, ou seja, ela impõe a interpretação do ambiente em que a problemática acontece, implicando em um ambiente natural das pessoas e o ambiente em pesquisa, essa abordagem também necessita segundo o mesmo autor que o pesquisador entreviste indivíduos e avalie observações, coletando evidências, sendo sua interpretação e análise visual também importante na coleta de informações.

Segundo aponta Gil (2010), os estudos podem ser classificados quanto aos objetivos, que podem ser descritivos, exploratórios ou explicativos como também pelos métodos e procedimentos utilizados para a sua realização. Para tanto as pesquisas também precisam utilizar-se de um delineamento para o seu desenvolvimento, que para Gil (2010), delinear uma pesquisa tem a significação de planejá-la, em sua 
dimensão mais abrangente e isso está junto com os fundamentos e métodos, alinhados com a definição dos objetivos, o ambiente de pesquisa, instrumento e procedimento de coleta de dados.

A primeira etapa desse projeto consiste em observar a comunidade, utilizando-se nessa etapa da técnica de observação participante de modo a caracterizá-la mais profundamente, através da criação de laços e perceber através de rodas de conversas com os seus problemas, as suas necessidades, as aspirações sentidas, os valores, as representações com a finalidade de criar um mapa da comunidade. Vista dessa forma, a participação deve ser concebida como um ato interativo entre os diversos atores sociais, na perspectiva de conhecer o contexto no qual estão inseridos, e entender a interação dos saberes empíricos sobre a sustentabilidade relacionando com o saber científico.

\section{Lócus do estudo}

Os Sítios Cruzeiro e Jatobá, localizam-se na Chapada do Araripe, zona rural do distrito de Santa Fé distantes aproximadamente quinze quilômetros do município do Crato pertencente a região metropolitana do Cariri no extremo sul do Ceará. A comunidade sobrevive de agricultura familiar e benefícios sociais, e no período de novembro a março, comercializa o fruto pequi, sendo que esse fruto é altamente perecível, precisa ser comercializado logo após a sua colheita, portanto percebeu-se o desperdício, e desvalorização econômica no período de safra, a implementação de um galpão de beneficiamento permitirá a essas famílias congelar o pequi e não mais desperdiçar obtendo uma valorização econômica trazendo como consequência, supõe-se que ocorra uma mudança de vida na comunidade, importante para ser registrada como exemplo de desenvolvimento sustentável.

\section{Sujeitos do estudo}

Quanto à delimitação serão acompanhadas os 25 representantes (homens e mulheres) das famílias envolvidas com o projeto pequi vivo e associação de moradores, que acompanhados por um grupo de alunos e professores de uma faculdade privada da região e em parceria com o financiamento de um banco está implementando um galpão de beneficiamento de pequi, e para responder o instrumento de coleta de dados foram eleitos por questões aleatórias onze representantes dos núcleos familiares moradores dessa comunidade.

\section{Período de realização da pesquisa}

A construção do projeto de pesquisa surgiu a princípio depois das primeiras visitas a comunidade em setembro de 2014, a pesquisadora ao entrar em contato com a comunidade percebeu a carência em todos os aspectos naqueles moradores, essa visita inicial deu-se para a execução de um projeto de extensão cujo objetivo era elaborar projetos para melhorar a qualidade de vida daqueles os quais os alunos elegiam; e logo nas primeiras visitas identificou-se que os moradores dessa comunidade tinham o acesso muito restrito a água, sendo este bem primordial a existência humana, através de políticas públicas tiveram o acesso as cisternas de placas, e captam a água das chuvas que abastecem essas cisternas para o uso doméstico, porém 
a quadra invernosa tem ficado cada vez menor e menos milímetros têm sido armazenados, nos meses de agosto até as próximas chuvas os moradores dessa comunidade são abastecidas por caminhões pipa que comercializam água uma vez por semana para os moradores que conseguem adquirir.

Conversando com os moradores logo detectou-se que a principal renda da comunidade é a aposentadoria e benefícios sociais, sendo o principal deles o bolsa família e o 'protagonista' identificado por eles como a principal fonte de renda sendo a coleta de pequi, elencada como a segunda maior fonte de renda dos moradores.

A observação e coleta de dados para esse estudo deu-se a partir do primeiro contato com essa comunidade desde setembro de 2014 até dezembro de 2017 coma última visita para estudo com essa comunidade; As visitas de observação realizaram-se quinzenalmente durante esse período sempre acompanhando as ações do projeto de extensão junto ao grupo de alunos, e relacionando com anotações as percepções dos moradores com as intervenções, como também seu modo de viver com relação as dimensões da sustentabilidade.

\section{Instrumento de coleta de dados}

Como ferramenta de coleta de dados foram utilizadas a observação assistemática participante e a as rodas de conversas com os membros para a identificação dos impactos gerados na vida da comunidade como empoderamento, trabalho em equipe, e relação com o meio ambiente, utilizar-se-á um questionário estruturado com vinte umas perguntas para a coleta de informações com os representantes dos núcleos familiares eleitos para serem os respondentes da pesquisa por ordem aleatória. O questionário foi dividido em cinco blocos para melhor constituir a análise de resultados; O primeiro bloco questiona sobre o perfil do respondente coletou-se informações sobre: Idade, gênero e renda familiar. O segundo bloco buscou identificar as dimensões sociais, culturais e territoriais da sustentabilidade nesses núcleos familiares, então perguntou-se sobre a situação familiar para identificar as novas formações familiares e os chefes de família, há quanto tempo residem nessa comunidade, para entender a relação deles com o território, o grau de escolaridade , experiência profissional e atividades associativas, sociais culturais e religiosas que participam para relacionarmos com a dimensão social/cultural da sustentabilidade.

O terceiro bloco foi constituído de questões sobres as fontes de renda principais e secundárias, as principais atividades econômicas praticadas para relacionar a dimensão econômica da sustentabilidade. No quarto bloco perguntou-se sobre os líderes da comunidade e suas representações na política, como também sobre as políticas públicas que conhecem e participam, e esse bloco relacionou-se sobre a dimensão política da sustentabilidade. No bloco cinco questionou-se sobre a relação da comunidade com a dimensão ecológica/ambiental da sustentabilidade, como o principal destino dos resíduos sólidos e os orgânicos, se existe saneamento e como fazem para se desfazer das águas servidas, se utilizam agrotóxicos, como limpam o roçado para plantação. 


\section{Procedimento de coleta de dados}

Ao ingressar no curso de mestrado em desenvolvimento regional sustentável, PRODER, na UFCA, foi comunicado a comunidade que eles estavam participando de um estudo e foi acordado com eles, sem nenhuma objeção para serem realizados as anotações e fotos desde março de 2016, com registros oficiais para o estudo, sendo que a comunidade já estava sendo acompanhada pela autora desde setembro de 2014, como já fora mencionado anteriormente.

A participação da pesquisadora na construção do projeto pequi vivo fora essencial para a coleta de informações da construção desse estudo, esta foi membro atuante durante as conversas e reuniões dos membros da comunidade no cotidiano da sua vivência; foram acompanhadas reuniões da associação de moradores, como também conversas informais com os mesmos, e participação do projeto pequi vivo na sede da associação e todas as ações do projeto foram acompanhadas in loco pela autora da pesquisa, constituindo assim uma observação participativa. A aplicação do questionário aos representantes dos onze núcleos familiares se deu no dia onze de novembro de 2017, na sede da associação de moradores, convidamos aos que quisessem ir participar dessa etapa da pesquisa e os representantes se dispuseram a responder.

\section{Análise dos dados}

Para a análise dos resultados foi utilizado o método proposto por Bardin de análise de conteúdo.

\section{Aspectos éticos da pesquisa}

Tendo em vista a ética em pesquisa, preestabelecida pela CONEP junto aos CEPs, este trabalho respeitará os preceitos éticos da resolução 510/2016, que segue as indicações da resolução 466/2012 quanto a beneficência, não maleficência aos seres humanos envolvidos no desenvolvimento da mesma. Desse modo, será utilizado o Termo de Consentimento Livre e Esclarecido (TCLE), destacando não apenas os objetivos, como também deixando claro que o participante não sofrerá nenhum dano, e riscos que por ventura surjam serão minimizados com a presença do pesquisador esclarecendo as possíveis dúvidas, não sendo invasivo na investigação e o deixando livre para tirar o seu consentimento a qualquer momento. As falas serão preservadas, utilizando-se pseudônimos e garantindo o anonimato do participante.

\section{RESULTADOS E DISCUSSÃO}

\section{As dimensões da sustentabilidade e as comunidades rurais dos sítios cruzeiro e jatobá}

A entrevista aos núcleos familiares ocorreu no dia 10 de novembro de 2017, como já havia um convívio da pesquisadora com a comunidade rural em estudo, foi livre a escolha dos respondentes, foram entrevistados 11 representantes dos núcleos familiares dos sítios Cruzeiro e Jatobá, as entrevistas foram realizadas na associação dos moradores da comunidade.

O questionário aplicado foi dividido em cinco blocos para melhor construção da análise de resultados: 0 primeiro bloco foi constituído de forma a construir um perfil do núcleo familiar daquela 
comunidade, coletou se dados acerca da idade, sexo, e renda familiar; O bloco dois complementa o primeiro para a compreensão sobre a formação dos núcleos familiares escolaridade, experiência profissional, e atividades que participam associativas ou culturais;

A pesquisa tem por objetivo central analisar os desafios da sustentabilidade nas comunidades rurais dos sítios Cruzeiro e Jatobá, para alcançar esses objetivos foram destinados os blocos seguintes, os questionamentos foram subdivididos nas dimensões da sustentabilidade apontadas por Sachs (2000) e são elas: Bloco três a dimensão econômica para o entendimento da principal renda da comunidade e atividades secundárias; no Bloco quatro foram questionados sobre a dimensão política para o entendimento sobre as suas lideranças e acesso a políticas públicas, e pôr fim a dimensão ecológica para a análise das relações da comunidade rural com a natureza, destinação de resíduos água e saneamento energia elétrica entre outros. As dimensões sociais, culturais e territoriais foram contempladas no bloco dois onde foram questionados sobre suas relações sociais entre si, e com a comunidade, como também formas de associações, projetos que participam e atividades culturais

\section{Caracterização sócio demográfico e econômico dos núcleos familiares}

As idades dos respondentes em seus núcleos familiares variam entre vinte e cinco e setenta e três anos, dentre os onze entrevistados quatro homens e sete mulheres. Os núcleos familiares são formados em média de três a cinco pessoas, onde percebeu-se que em sete das entrevistadas estas desempenham o papel de chefe e/ou responsável pela família todas com filhos e foram deixadas pelos seus maridos afirmando todas que eles foram procurar emprego em outros lugares pois não conseguiam sustentar a família estando apenas na comunidade, das entrevistadas em questão nenhum dos esposos que partiram enviaram qualquer contribuição para o núcleo familiar que foi deixado, tendo as mulheres que se reinventarem para manterem as suas famílias, nenhuma das entrevistadas pensou em abandonar o seu território e nem a prole constituída, tomaram elas para si a responsabilidade.

Analisou se também a formação dos núcleos familiares entrevistados e com relação ao gênero identificou-se que dos questionados dezenove são homens e vinte e uma são mulheres, sendo estes adultos e crianças com idades variadas entre três e setenta e três anos, eles afirmaram que a comunidade é composta mais por adultos jovens e idosos e poucas crianças. Quanto a escolaridade identificou-se que existem analfabetos na comunidade dos entrevistados cinco pessoas dos núcleos familiares se encontram nessa situação cinco afirmaram saber ler e escrever o básico treze terminaram o quarto ano oito frequentaram o ensino médio, mas não concluíram e seis concluíram e três cursam o ensino superior.

Complementando com a pesquisa observacional e diário de campo percebe-se nessa comunidade o difícil acesso à escola, esta fica um pouco distante da comunidade onde há a necessidade do transporte escolar e este segundo os moradores quebra muito, e muitos precisam caminhar até chegar a escola mais próxima, e geralmente nos primeiros meses do ano fica um acesso muito difícil devido ás chuvas, chegando alguns deles a desistirem. 
Quando questionados sobre a experiência profissional percebeu-se que habitando em um lugar de clima privilegiado, a chapada do Araripe, em sua maioria se dedicam a agricultura de subsistência e/ou familiar sendo essa considerado uma das principais práticas de trabalho dessa comunidade, vindo a seguir a coleta do pequi , não destacada como atividade principal por acontecer sazonalmente, depois enfatizaram os trabalhos domésticos e um número muito pequeno afirma praticar a atividade de comércio, nenhum dos entrevistados destacou os empregos urbanos, alguns também realizam atividade de pedreiro na comunidade como também alguns trabalhos associativos.

\section{Dimensão espacial e/ou territorial}

Silvino (2013) caracterizou as comunidades dos sítios Cruzeiro e Jatobá afirmando que ocupam uma área de aproximadamente $21.300 \mathrm{Km}^{2}$, delimitadas pelas coordenadas geográficas: latitude $\left(7^{\circ} 10^{\prime} 05^{\prime \prime} \mathrm{e}\right.$ $7^{\circ} 12^{\prime} 15^{\prime \prime}$ Sul); e longitude (39 $11^{\prime} 17^{\prime \prime}$ e $39^{\circ} 29^{\prime} 06^{\prime \prime}$ Oeste) (ver mapa 5.1). Territorialmente, constituem uma só superfície de terras contíguas entre si, pertencentes à zona rural do distrito de Santa Fé e distantes cerca de 15 km da sede do município do Crato, na microrregião do Cariri, no extremo sul do estado do Ceará.

Quando a comunidade é questionada sobre quanto tempo habitam nesse território eles responderam todos que habitam no local desde que nasceram, variando entre dois respondentes que dizem habitar na comunidade acerca de dez a onze anos, acrescentando a observação assistemática de convivência e constituição de diário de campo sobre a relação dessa comunidade sobre seu território eles relatam uma felicidade e privilégio em morarem na zona rural da Chapada do Araripe, a vida simples os encantam e dizem não querer trocar pela turbulenta zona urbana 'escutar o canto dos passarinhos e tomar um café embaixo do pé de pequi não tem coisa melhor' afirma uma moradora. Outro morador afirma. Moro aqui desde que nasci, não quero ir embora nem que meus filhos saiam daqui se tivesse coisa para eles fazerem aqui, percebe se na fala do morador que existe um amor ao seu espaço, e o desejo que as futuras gerações permaneçam nesse território, mas já se nota um pesar em sua fala por perceber que talvez seus filhos não permaneçam.

\section{Dimensão econômica}

Dentro dessa dimensão os moradores forma questionados sobre a principal fonte de renda, identificou-se que a maioria dos moradores dessa comunidade sobrevivem da aposentadoria rural ou benefício, de pelo menos um dos membros da família sendo seguido do programa assistencialista do bolsa família, essas duas fontes de renda foram as mais citadas pelos núcleos familiares respondentes a pesquisa, apenas dois dos entrevistados mencionaram ter empregos urbanos, e todos os núcleos familiares, sem exceção responderam realizar a coleta do pequi para sobrevivência e ressaltam ser a atividade econômica mais rentável para eles, e só não se tornam a principal renda pelo motivo do pequi ser um fruto sazonal.

$\mathrm{Na}$ entre safra do pequi, onde a maioria dos moradores dessa comunidade se encontra sem sua principal fonte de renda, muitos se aventuram em participar da colheita em outros estados como Minas gerais, e Rio Grande do Sul, vale salientar que as condições de viagem e permanência do trabalho nesses estados caracteriza-se como trabalho escravo, segundo eles afirmam. 
Os que permanecem na comunidade fazem a prática da agricultura de subsistência tendo como principais produtos: o milho, o feijão, verduras como o tomate, alface e coentro e a macaxeira, alguns são cadastrados pela associação e comercializam muito pouco na merenda escolar e nem citam essa prática como fonte de renda.

\section{Dimensão política}

Nos limites da comunidade em questão, todos os moradores questionados afirmaram não haver nenhuma liderança ou representante político nas esferas do poder público, mas dizem ser organizados através de uma associação de moradores onde se reúnem no primeiro sábado do mês para discutirem questões de necessidade da comunidade, como por exemplo o acesso a água encanada, melhoria de estradas, saúde, educação e melhorias para a comunidade.

Nos tempos de eleição os candidatos ao poder público visitam a comunidade, fazem promessas, mandam carros para levar os moradores aos comícios e carreatas, pagam combustível, mas esses afirmam que logo que eleitos eles desaparecem da comunidade retornando apenas nos próximos pleitos eleitorais. Identificou-se que os moradores possuem o entendimento e o conhecimento das políticas públicas que podem ter acesso, e quando questionados sobre a sua participação nas mesmas, eles afirmaram, todos, que utilizam o Sistema único de saúde o SUS, e recebem a visita dos agentes de saúde, não utilizam o programa de distribuição de sementes e um afirmou utilizar o programa de microcrédito e distribuição de sementes.

\section{Dimensão ecológica}

Os sítios Cruzeiro e Jatobá localizam-se na Chapada do Araripe, é uma área repleta de plantas e árvores pesquisadas no mundo inteiro e animais de floresta, por ser visitada por estudantes e pesquisadores, as instituições como IcmBio, Embrapa, IFCE e ONGs tem se preocupado em realizar rodas de conversa sobre educação ambiental nessa comunidade, apesar dos moradores conhecerem e entenderem o que devem fazer com relação a proteção da Chapada a pesquisa nos mostrou que não o fazem.

Questionou-se aos moradores sobre o destino dos resíduos sólidos eles responderam que os resíduos orgânicos são utilizados como alimentação para os animais domésticos (cachorros e gatos) e para os animais de criação como galinhas e porcos. Sobre o lixo seco e embalagens, a maioria afirma queimar o lixo ou enterrá-lo, afirmam existir a coleta de lixo pública, porém essa só passa uma vez por semana em pontos específicos, afirmam eles terem que percorrer distâncias consideráveis para transportar os resíduos, além de ter cuidado com seu armazenamento até o dia da coleta, preferem não o fazer, pois o armazenamento atrai insetos, como moscas ratos e baratas.

O saneamento, assim como na maioria das regiões do Brasil, quanto mais na zona rural, não há. Os que possuem mais condições financeiras constroem suas fossas sépticas, mas ainda é identificado uma grande maioria de latrinas /buracos no chão são utilizados para as fezes e urina e as águas servidas de pia e banho são liberadas a céu aberto. 
Sobre as práticas ambientais mesmo com todas as orientações mencionadas acima a maioria respondeu que queima o roçado para limpar o terreno, e derrubam árvores para fazer carvão, pois em sua maioria ainda se utilizam de fogão a lenha. Porém destaca-se nessa comunidade a não utilização de inseticidas ou agrotóxicos químicos, dizem que quando precisam se livrar de alguma praga como as formigas, utilizam a pimenta como inseticida natural.

\section{Comunidade rural dos cruzeiro e jatobá e o projeto pequi vivo}

A comunidade Jatobá/Cruzeiro, apesar de ser formada por dois sítios (Jatobá e Cruzeiro), concentra aspectos comuns da realidade social, econômica, cultural e, principalmente política, em face da existência de uma só associação de moradores. A comunidade dos Sítios Cruzeiro e Jatobá tem sido acompanhada, por um grupo de alunos e professores de um centro universitário da cidade de Juazeiro do Norte desde 2013, com o propósito do desenvolvimento de um projeto de extensão que tem por objetivo desenvolver ações de empoderamento e responsabilidade social da instituição de ensino superior para a comunidade.

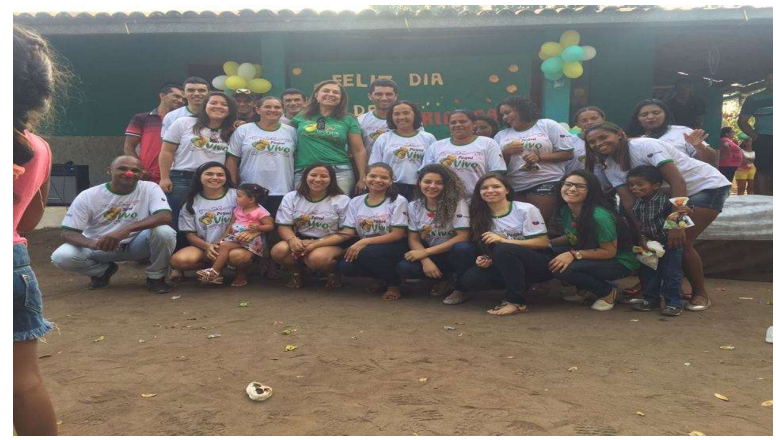

Figura 3.

A comunidade está ativamente envolvida com o projeto pequi vivo, as reuniões ocorrem quinzenalmente, e participam cerca de 25 representantes das familias envolvidas, ao longo. 0 grupo de trabalho externo a comunidade, alunos e professores, concorreu a um edital do grupo Santander Universidades, e foi vencedor com uma premiação de $100.000,00$, valor esse a ser investido no projeto denominado por Pequi vivo, localizado na associação dos sítios Cruzeiro e Jatobá.

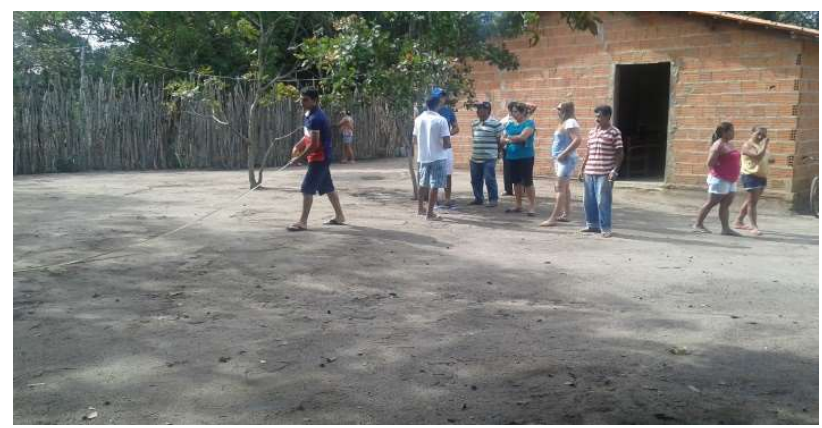

Figura 4.

Aprende-se que administrar um prêmio dessa magnitude é um trabalho árduo que precisa de muita dedicação e amor, desenvolveu-se a verdadeira essência da extensão universitária que é olhar a necessidade 
do outro e ser útil a ele com os conteúdos assimilados na universidade, melhorar a vida de alguns próximos a nós e nos considerarmos felizes por isso.

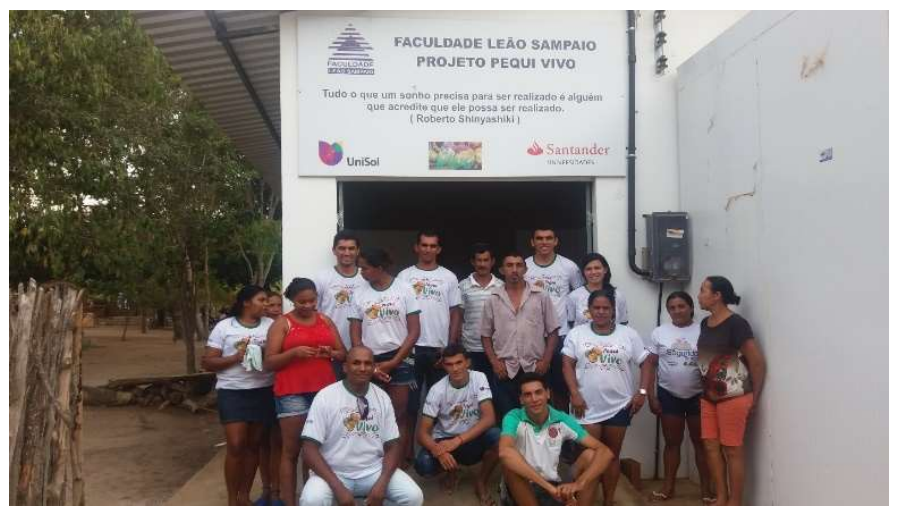

Figura 5.

Porém durante a convivência na comunidade fez-se perceber a carência em saúde e foram incluídas algumas orientações sobre saúde, além do empreendedorismo social já em ação pelo projeto. A presença da universidade na comunidade, foi essencial para o desenvolvimento do projeto, pois a mesma se sentia privilegiada com a presença dos mesmos, ao mesmo tempo que transmite, uma imagem de segurança e competência.

Foi desenvolvido um serviço de atividades lúdicas para as crianças da comunidade, pois os pais levavam os filhos para as reuniões e os mesmos não permitiam que os pais se concentrassem para tanto firmou-se uma parceria com o curso de psicologia e foram desenvolvidas atividades para as crianças e esse projeto culminou no dia das crianças, onde foi realizado um dia festivo na comunidade.

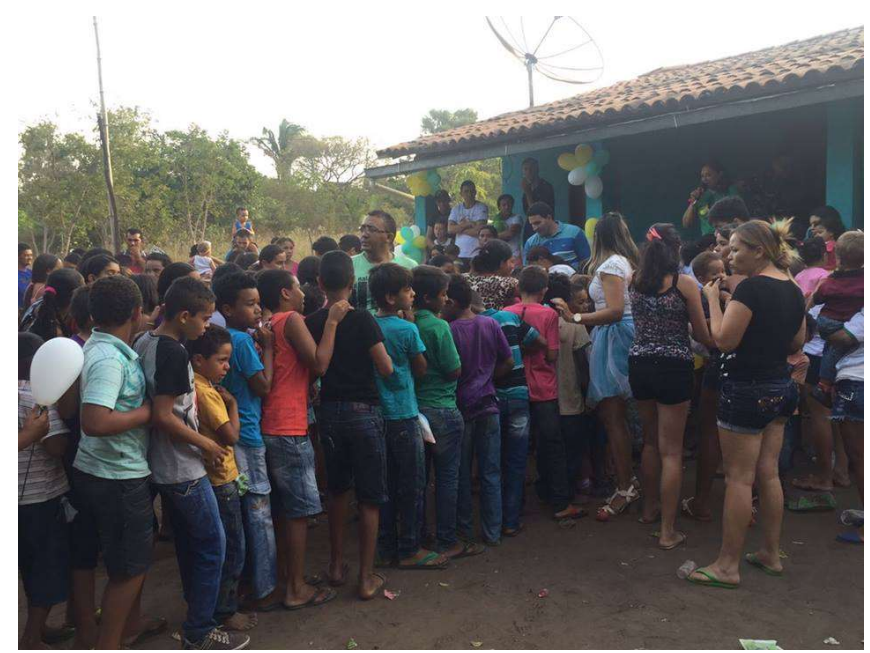

Figura 6.

Outro serviço foi a necessidade relatada por eles de saúde bucal, onde firmou-se uma parceria com o curso de odontologia e foi desenvolvido uma orientação geral de higienização bucal, com posterior aplicação de flúor e parceria com a clínica escola para dar continuidade aos tratamentos, iniciando pelos mais urgentes já detectados na própria comunidade. Recentemente devido a atividade de coleta do pequi, foi percebido a necessidade de ter uma parceria com o curso de fisioterapia para realizar uma avaliação postural, com posterior orientações para atividades da vida diária. 


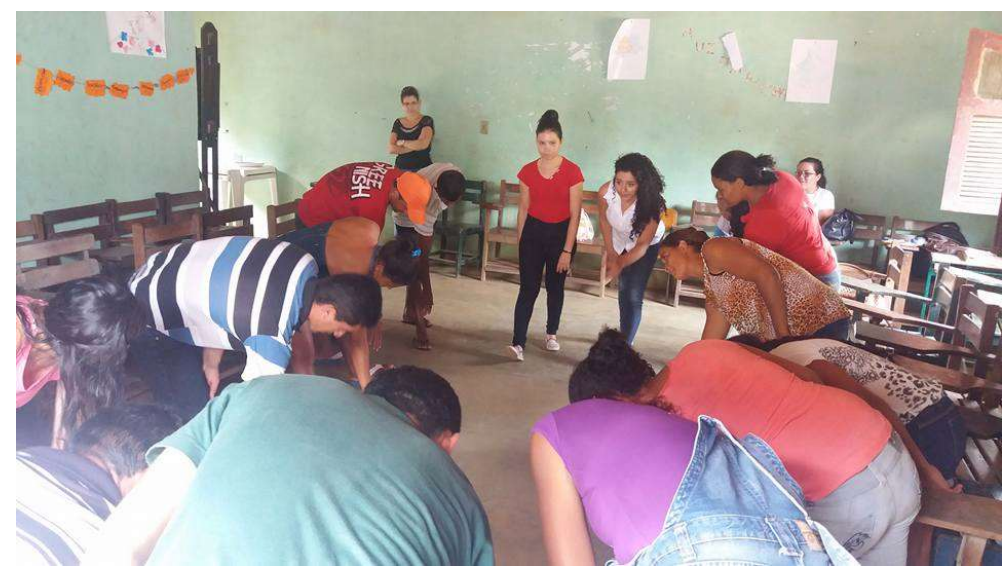

Figura 7.

O projeto pequi vivo está no terceiro ano de ação na comunidade dos sítios Cruzeiro e Jatobá, e percebe-se a quantidade de ações realizadas, na parceria universidade e comunidade, que por vezes tornase um ator de política pública executada por pessoas que acreditam no empreendedorismo social e na contribuição com a melhoria da qualidade de vida das comunidades rurais.

\section{CONCLUSÕES}

O desenvolvimento sustentável, aquele que preconiza a qualidade de vida dos presentes sem comprometer as futuras gerações, precisa sair do discurso em todas as esferas sociais, sabe-se que em pequena escala essa utilização adequada dos recursos naturais existe e o 'pequi vivo', é um grande exemplo dessa realidade, uma comunidade rural que se organizou em uma associação, para resolver suas questões sociais, recebeu a visita de um grupo de estudantes de administração para uma conversa sobre a vida e a coleta de pequi na serra, e desta surgiu a problemática do desperdício e desvalorização do fruto, e esses alunos submeteram o projeto e receberam o dinheiro para desenvolver o galpão de beneficiamento de pequi do lado da associação que eles se reuniam, daí em diante a comunidade iniciou o processo de mudança e a esperança de trabalho, valorizando o seu lugar. $\mathrm{O}$ envolvimento da comunidade trouxe à tona a valorização do trabalho no campo, como também uma proposta de empoderamento e a sustentabilidade do local.

\section{REFERÊNCIAS}

BARBIERI, J. C.. Gestão ambiental empresarial: conceitos modelos e instrumentos. 3 ed. São Paulo: Saraiva, 2011.

BARBOSA, G. S.. O desafio do desenvolvimento sustentável. Revista Visões: Rio de Janeiro, 2008.

BOSSELMAN, K.. O Princípio da Sustentabilidade: transformando o direito e governança. 1 ed. São Paulo: Revista dos Tribunais, 2015.

BURSZTYN, M.. Ciência, ética e sustentabilidade. 2 ed. São Paulo: Cortez; Brasília: UNESCO, 2007.

BURSZTYN, M.. O poder dos donos: planejamento e clientelismo no Nordeste. 3 ed. Rio de Janeiro: Garamound; Fortaleza: BNB, 2008.
CHACON, S. S.. O sertanejo e o caminho das águas: políticas públicas, modernidade e sustentabilidade no semi-árido. Fortaleza: BNB, 2007.

DIAS, R.. Gestão ambiental: responsabilidade social e sustentabilidade. São Paulo: Atlas, 2011.

FRANÇA FILHO, G. C.. A Economia Solidária: uma abordagem internacional. Porto Alegre: Editora da UFRGS, 2004.

GIL, A. C.. Como Elaborar Projetos de pesquisa. 5 ed. São Paulo: Atlas 2010. 
HAESBAERT, R.. A multiterritorialidade do mundo e o exemplo da Al Qaeda. Terra Livre, São Paulo, v.1, n.18, p.3746, 2002.

JIMENEZ, S.; TERCEIRO, E.. A crise ambiental e o papel da educação: um estudo fundado na ontologia marxiana. Educ. ver., v.25, n.3, p.299-325, 2009.

LEFF, E.. Ecologia, capital e cultura: a territorialização da racionalidade ambiental. Petrópolis: Vozes, 2009.

MATOS, F. J. A.. Plantas medicinais: guia de seleção e emprego de plantas usadas em fitoterapia no Nordeste do Brasil. 3 ed. Fortaleza: Imprensa Universitária, 2007.

OLIVEIRA, M. E. B.; GUERRA, N. B.; BARROS, L. M.; ALVES, R. E.. Aspectos agronômicos e de qualidade do pequi. Fortaleza: Embrapa Agroindústria Tropical, 2008.

PASQUAL, M. O. A.; FACHINI, M. P.. Espaços verdes urbanos importância na dinâmica da cidade. Umuarama: SEED, 2008.

PEREIRA, A. C.; SILVA, G. Z.; CARBONARI, M. E. E.. Sustentabilidade, responsabilidade social e meio ambiente, São Paulo: Saraiva, 2011.

PHILIPPI JR., A.; PELICIONI, M. C. F.. Educação ambiental e sustentabilidade. Barueri: Manole, 2014.

RAFFESTIN, C.. Por uma geografia do poder. São Paulo: Ática, 1993.
ROESLER, R.; MALTA, L. G.; CARRASCO, L. C.; HOLANDA, R. B.; SOUSA, C. A. S.; PASTORE, G. M.. Atividade antioxidante de frutas do cerrado. Ciência e Tecnologia de Alimentos, v.27, n.1, p.53-60, 2007

SACHS, I.. Caminhos para o desenvolvimento sustentável. Rio de Janeiro: Garamound, 2002.

SACHS, W.. Dicionário de desenvolvimento: guia para o conhecimento como poder. Petropólis: Vozes, 2000.

SANTOS, M.. Metamorfose do Espaço Habitado. 1988.

SEVERINO, A. J.. Metodologia do trabalho científico. 24 ed. São Paulo: Cortez, 2016.

SILVINO, P. S. N.. Gestão em áreas protegidas: proposição metodológica para análise de impactos socioambientais nas comunidades tradicionais da APA Chapada do Araripe / Paulo Sérgio Silvino do Nascimento. Rio Claro, 2013.

SINGER, P.. Introdução à economia solidária. 1 ed. São Paulo: Fundação Perseu Abramo, 2010.

VALLE, C. E.. Qualidade Ambiental: ISO 14000. São Paulo: Senac, 2004.

ZAOUAL, H.. Nova economia das iniciativas locais: uma introdução ao pensamento pós globais. Rio de Janeiro: COPPE/UFRJ.

A CBPC - Companhia Brasileira de Produção Científica (CNPJ: 11.221.422/0001-03) detém os direitos materiais desta publicação. Os direitos referem-se à publicação do trabalho em qualquer parte do mundo, incluindo os direitos às renovaç̃ões, expansões e disseminações da contribuiç̃o, bem como outros direitos subsidiários. Todos os trabalhos publicados eletronicamente poderão posteriormente ser publicados em coletâneas impressas sob coordenação da Sustenere Publishing, da Companhia Brasileira de Produção Científica e seus parceiros autorizados. Os (as) autores (as) preservam os direitos autorais, mas não têm permissão para a publicação da contribuição em outro meio, impresso ou digital, em português ou em tradução. 